\title{
High prevalence of missed information related on bone health in orthogeriatric patients with fragility fractures of the pelvis-an institutional register-based analysis
}

\author{
J. Gleich ${ }^{1}$ A. Cavalcanti Kußmaul ${ }^{1}$ E. Steiner ${ }^{1}$ - W. Böcker ${ }^{1} \cdot$ C. Neuerburg ${ }^{1} \cdot$ C. Linhart ${ }^{1}$
}

Received: 12 June 2021 / Accepted: 18 November 2021 / Published online: 24 November 2021

(c) The Author(s) 2021

\begin{abstract}
Summary This is the first study that highlighted the amount of missed information related on bone health in orthogeriatric patients suffering fragility fractures of the pelvis and also evaluated its prevalence and differing etiology in the assessed patients, regarding osteoporosis and/or osteomalacia, based on laboratory and instrumental measurements. This evaluation should become a standardized procedure in the treatment of orthogeriatric patients presenting with a FFP.

Introduction Fragility fractures of the pelvis (FFP) are common in orthogeriatric patients. Secondary fracture prevention regarding evaluation and treatment of an underlying osteoporosis or osteomalacia is still often neglected. The purpose of this study was to evaluate the amount of missed information related on bone health in older adult FFP patients, the prevalence of vitamin D deficiency in assessed patients, and if fracture type-dependent distribution patterns could be observed.

Methods A retrospective analysis of prospectively collected data of an institutional register was performed. Patients aged 80 years and older $(n=456)$ admitted with a FFP from 01/2003 until 12/2019 to a level I trauma center were included.

Results In 456 patients, FFP type II were leading (66.7\%). Diagnostics were conducted in $37.1 \%$ of the patients regarding measurement of vitamin D levels and 21.7\% regarding DXA measurements; vitamin D deficiency was observed in $62.7 \%$, indicators for an underlying osteomalacia in $45.8 \%$, and an osteoporosis in $46.5 \%$ of the assessed patients.

Conclusion Although FFP are common and will increase, there is still a lack of secondary fracture prevention, starting with information related on bone health. In the assessed patients, a high prevalence of vitamin D deficiency was present, but no significant correlation between vitamin D level and type of fracture was observed. Ongoing education for varying etiology and specific treatment of these fractures is necessary, as surgical treatment was unified, but drug therapy remains different.
\end{abstract}

Keywords Fragility fracture of the pelvis · Orthogeriatric $\cdot$ Osteomalacia · Osteoporosis · Pelvic insufficiency fracture · Vitamin D insufficiency

\section{Introduction}

Demographic changes lead to a continuous increase in the geriatric population. Due to improvements in living conditions and medical care, the life expectancy in this collective is also rising, and a tripling of the geriatrics aged 85 years and older up to 19 million in 2050 is expected [1, 2]. Besides common age-related comorbidities like hypertension or

C. Linhart

christoph.linhart@med.uni-muenchen.de

1 Department of Orthopaedics and Trauma Surgery, Musculoskeletal University Center Munich (MUM), University Hospital, LMU Munich, Marchioninistr. 15, 81377 Munich, Germany diabetes, osteoporosis often remains undiagnosed and is not assessed until a fall and following fracture [3]. Despite this diagnostic failure, osteoporosis prevails around the world. Almost 8 million patients are affected by an underlying osteoporosis in Germany with an age-dependent prevalence: While women older than 50 years showed a prevalence of $24 \%$, there was an increase up to $30 \%$ in woman older than 75 years [4-6]. This is of clinical significance, as a simultaneous increase of so-called fragility fractures can be observed [6,7]. A fragility fracture is defined by the occurrence due to inadequate trauma, which not typically results in a fracture. The World Health Organization (WHO) specified this "low-energy" trauma as forces equivalent to a fall from a standing height or less [8]. In the inpatient setting, the proportion of fragility fractures also shows an 
age-dependent increase up to $95 \%$ in patients aged 75 years and older [9]. In addition to fractures of the hip or spine, fragility fractures of the pelvis are frequent and increasing; in the USA, geriatric pelvic ring fractures multiplied by $24 \%$ from 1993 to 2010 [4].

Usually, classification and treatment of pelvic ring fractures follow the worldwide used AO/OTA Fracture and Dislocation Classification [10]. The differing genesis of pelvic ring fractures in the elderly remains unconsidered in this classification. Therefore, Rommens and Hoffmann developed a new classification system and subsequent treatment options, taking into account the fragility aspect in these fractures [11] (Fig. 1). The fragility fracture of the pelvis (FFP) is associated with reduced bone quality and subsequent specific fracture patterns, only observed in FFP [12, 13]. Also insufficiency fractures, that occurred without a trauma, are included in this classification. They may develop especially in patients with osteomalacia, which is characterized by impaired mineralization of the bone and following bone weakness; vitamin D-dependent types have to be differentiated from hypophospatemic types [14]. The impact of vitamin D deficiency in FFP has been little studied, although in hip fracture patients high serum vitamin D levels were associated with reduced fracture risk, and also in geriatric vertebral fractures, this correlation was observed $[15,16]$.

The aim of this institutional register-based analysis was to identify the frequency of initiated diagnostic procedures for the underlying pathology during in-hospital stay of orthogeriatric patients suffering a FFP, and to evaluate the prevalence of vitamin D deficiency in assessed patients and if fracture type-dependent distribution patterns of serum 25(OH)-vitamin D levels could be observed.

\section{Methods}

This retrospective single-center study was approved and registered by the local ethics committee (Reg. No. 518-18). All patients aged $\geq 80$ years admitted to a level one trauma center with a fracture of the pelvic ring were included prospectively from $01 / 01 / 2003$ to $31 / 12 / 2019$ into an institutional registry. Exclusion criteria were defined as pathological fractures (spontaneous fractures occurring without any trauma), high energy trauma, elevated liver enzyme levels in the initial laboratory assessment, any type of cancer. All patients or their legal representative gave written informed consent for inclusion. The study was conducted in accordance with the Declaration of Helsinki.

Based on conventional radiographs of the pelvis (anteroposterior, inlet and outlet view) and subsequent computed tomography (CT) of the pelvis, all fractures were classified CT-based according to the FFP classification by Rommens et al. If conservative treatment was indicated, standardized pain medication following WHO (World Health Organization) treatment guidelines was administered, and mobilization by physiotherapists started as soon as possible with the goal of increasing weight-bearing of the injured site; if mobilization was impossible until 3 to 5 days after admission, operative treatment was performed. In all surgically treated patients, surgery was performed under general anesthesia by trauma specialists, according to the $\mathrm{AO}$ principles of fracture management and the recommendations for treatment of FFP by Rommens and Hoffmann (depending on fracture type: minimally invasive; open/closed reduction and internal fixation, bone cement application).

The FFP classification ranges from FFP type I to FFP type IV lesions and is based on the degree of instability (type
Fig. 1 Classification of fragility fractures of the pelvis according to Rommens and Hoffmann [11]. FFP type I: only anterior pelvic ring injury. FFP type II: non-displaced posterior pelvic ring injury. FFP type III: displaced unilateral posterior pelvic ring injury (in types II and III usually additional affection of the anterior pelvic ring). FFP type IV: displaced bilateral posterior pelvic ring injury
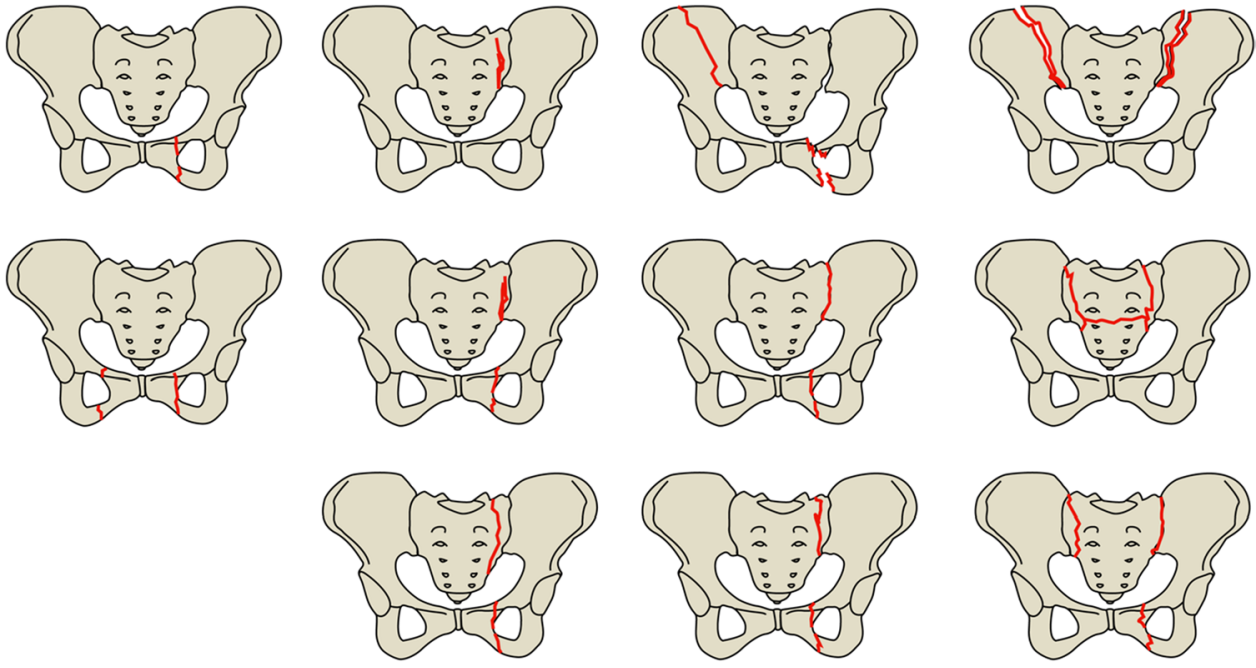

Type I

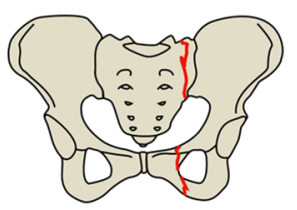

Type III

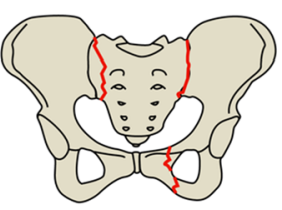

Type IV 
I: limited instability, type IV: highest instability; see Images 1 and 2). Osteoporotic, fatigue, and insufficiency fractures are subsumed in this classification [11].

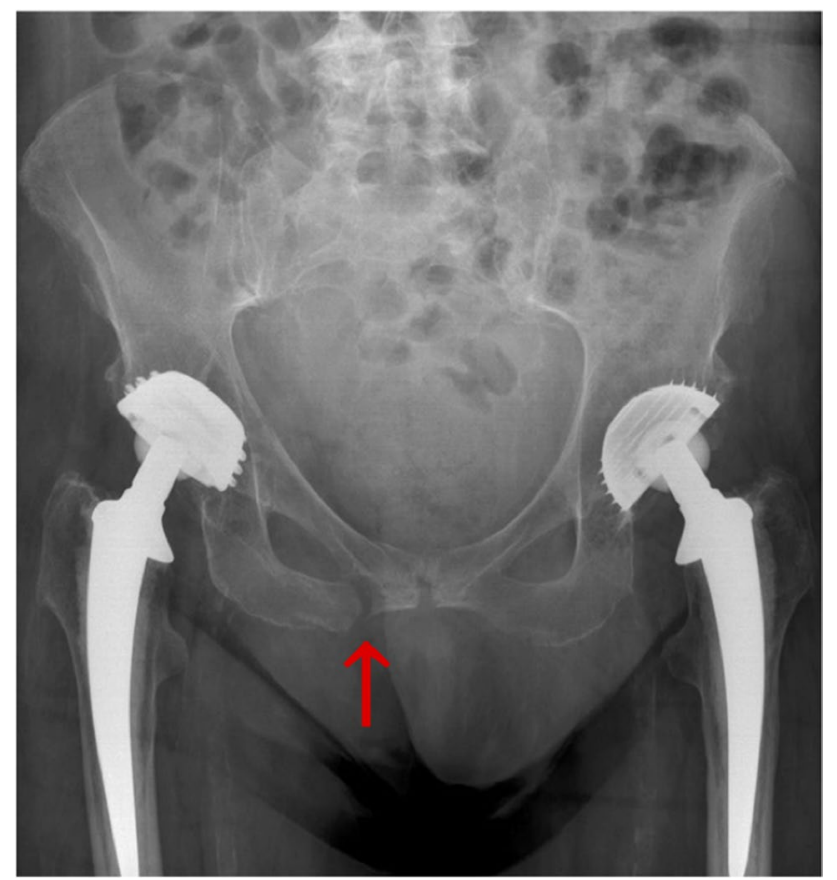

Image 1 X-ray of a patient (female, 94 years old) with a FFP Ia fracture on the right
Information related on bone health in orthogeriatric patients included standardized laboratory measurements (e.g., serum $25(\mathrm{OH})$-vitamin D level, calcium and phosphate levels, kidney and liver values) and subsequent bone density evaluation (DXA scan) during inpatient stay, if available.

Different assays for assessment of serum $25(\mathrm{OH})$-vitamin D level were used during the study period: The clinical medicine laboratory used the IDS RIA assay before 2010 . Subsequently, from November 2010 to July 2015, the IDS CLIA assay was used, from July 2015 to September 2020, DiaSorin CLIA; up to and including today, the Roche Diagnostics ECLIA Cobas assay is used. Vitamin D deficiency was defined as a serum-25(OH)-vitamin D of $<20 \mathrm{ng} / \mathrm{ml}$, vitamin D insufficiency as a serum-25(OH)-vitamin D of 21-29 ng/ml, and regular vitamin D levels as a serum$25(\mathrm{OH})$-vitamin D of $>30 \mathrm{ng} / \mathrm{ml}[17,18]$.

Bone density evaluation was performed by quantitative digital radiography in former times (QDR, DPX) and nowadays by dual-energy X-ray absorptiometry (DXA) devices. The study did not include patients, whose T-score was derived from a qCT measurement, to avoid bias of different measurement methods. Osteopenia was defined by a T-score from -1 to -2.5 standard deviations (SD), osteoporosis by a T-score $<-2 / 5$ SD [19].

Baseline data were collected from medical records, laboratory data, and radiological files, then stored with a standardized data management file (Excel 2011, Microsoft Cooperation, Redmond, USA). IBM SPSS Statistics, Version 26 (IBM Corp. Released 2016. Armonk, NY) was
Image 2 CT scan of a patient (female, 83 years old) with a FFP IIIc fracture on the left (A coronar view of the superior pubic ramus fracture; $\mathbf{B}$ coronar view of the sacral fracture; $\mathbf{C}$ axial view of the inferior pubic ramus fracture)

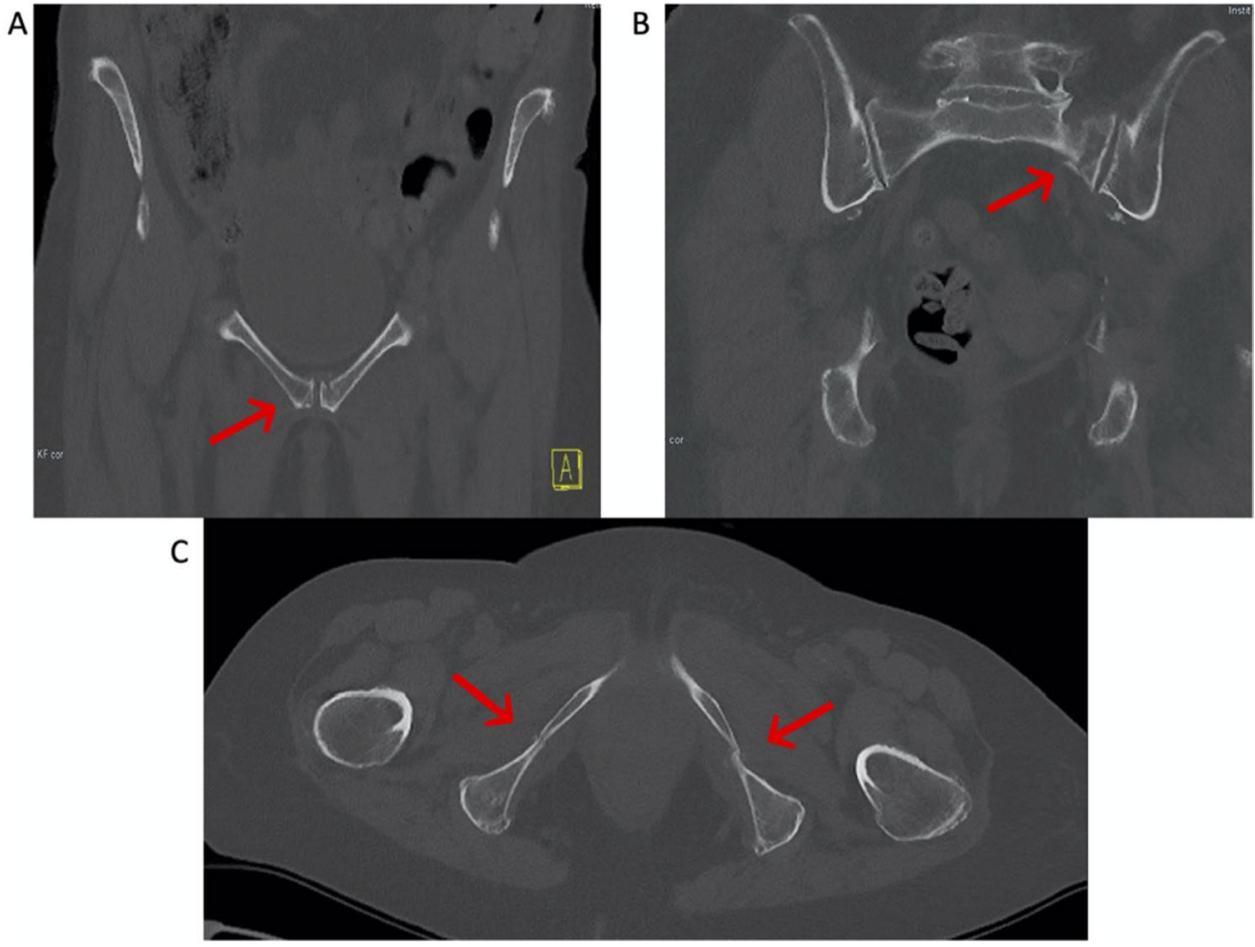


used for statistical analysis. Data are reported as either mean \pm standard deviation (SD) or for categorical data as absolute frequency with a percentage distribution. The Kolmogorov-Smirnov test was used for ruling out normal distribution, subsequently a Mann-Whitney $U$-Test or $t$-test was used, while Fisher's exact test was used for dichotome variables; for correlation analysis, the Pearson correlation coefficient was used. A $p$-value $<0.05$ was regarded to be statistically significant.

\section{Results}

Four hundred fifty-six patients with a mean age of 87.3 $( \pm 4.5)$ years were included for final analysis, $79.6 \%$ were female. A CT (computed tomography)-based diagnosis and classification of the FFP were performed in $100 \%$ of the cases and the major proportion was a FFP type II (66.7\%) (see Table 1). Conservative treatment was carried out in $84.9 \%$ of the patients, while $15.1 \%$ were treated surgically with significantly increasing proportion in unstable fracture patterns (see Table 2 for detailed information). Information related on bone health presented a vitamin D deficiency in $62.7 \%$ and an underlying osteopenia/osteoporosis (based on DXA results) in 34.3\%/46.5\% of the assessed patients; they were conducted in $37.1 \%$ of the patients regarding measurement of serum $25(\mathrm{OH})$ vitamin D levels and in $21.7 \%$ regarding a DXA scan (see Table 1). $14.7 \%$ of the patients demonstrated a previously diagnosed osteoporosis with basic anti-osteoporosis therapy (supplementation of vitamin D). Mean serum $25(\mathrm{OH})$-vitamin D levels varied significantly between the different FFP types with the highest mean in FFP type IV fractures (see Table 3 ). There was no significant correlation of serum 25(OH)-vitamin D levels and FFP fracture patterns. T-scores (measured by DXA scans of lumbar vertebrae and femoral neck) showed no significant differences between the groups, but a trend of increasingly negative $\mathrm{T}$-scores in higher grades of instability could be seen. Female patients presented with elevated alkaline phosphate (ALP) levels in all types of FFP; there was no significant difference, but also a trend towards higher alkaline phosphate levels in more complex types of FFP (see Table 3). Male patients demonstrated increased ALP levels in FFP types I and IV, without significant differences between the groups. Serum calcium and serum phosphate levels were normal, without significant intergroup differences. This was also seen in patients with vitamin D insufficiency (serum 25(OH)-vitamin D levels $21-29 \mathrm{ng} / \mathrm{ml}$ ) and regular vitamin D levels (serum 25(OH)-vitamin D levels $>30 \mathrm{ng} / \mathrm{ml}$ ) (Table 4).
Table 1 Baseline data

\begin{tabular}{|c|c|}
\hline Age, mean $\pm S D$ & $87.3 \pm 4.5$ \\
\hline \multicolumn{2}{|l|}{ Gender, $n(\%)$} \\
\hline $\begin{array}{l}\text { Male } \\
\text { Female }\end{array}$ & $\begin{array}{l}93(20.4) \\
363(79.6)\end{array}$ \\
\hline CT-based classification, $n(\%)$ & $456(100)$ \\
\hline \multicolumn{2}{|l|}{ FFP type, $n(\%)$} \\
\hline $\begin{array}{l}\text { I } \\
\text { II } \\
\text { III } \\
\text { IV }\end{array}$ & $\begin{array}{l}57(12.5) \\
304(66.7) \\
73(16.0) \\
22(4.8)\end{array}$ \\
\hline \multicolumn{2}{|l|}{ Treatment, $n(\%)$} \\
\hline $\begin{array}{l}\text { Conservative } \\
\text { Operative }\end{array}$ & $\begin{array}{l}387(84.9) \\
69(15.1)\end{array}$ \\
\hline Previously diagnosed osteoporosis, $n(\%)$ & $67(14.7)$ \\
\hline Laboratory vitamin D measurement, $n(\%)$ & $169(37.1)$ \\
\hline \multicolumn{2}{|l|}{$\begin{array}{l}\text { Mean vitamin D level (serum } 25(\mathrm{OH}) \text {-vitamin D in } \\
\mathrm{ng} / \mathrm{ml} \text { ) }\end{array}$} \\
\hline Male $^{\circ}$ & $13.89 \pm 13.45$ \\
\hline Female $^{\circ}$ & $16.23 \pm 15.35$ \\
\hline $\begin{array}{l}\text { Vitamin D deficiency*, } n(\%) \\
(\text { Serum } 25(\mathrm{OH}) \text {-vitamin D level }<20 \mathrm{ng} / \mathrm{ml})\end{array}$ & $106(62.7)$ \\
\hline \multicolumn{2}{|l|}{ DXA scan, $n(\%)$} \\
\hline Lumbar vertebrae & $99(21.7)$ \\
\hline Femoral neck & $99(21.7)$ \\
\hline \multicolumn{2}{|l|}{ Newly diagnosed osteopenia/osteoporosis*, $n(\%)$} \\
\hline T-score $-2.5--1$ in DXA scan (osteopenia) & $34(34.3)$ \\
\hline Mean vitamin $\mathrm{D}$ level ${ }^{\circ}$ & $16.59 \pm 12.64$ \\
\hline T-score $\leq-2.5$ in DXA scan (osteoporosis) & $46(46.5)$ \\
\hline Mean vitamin $\mathrm{D}$ level ${ }^{\circ}$ & $19.90 \pm 15.55$ \\
\hline
\end{tabular}

*In assessed patients; ${ }^{\circ}$ no significant differences $(p=0.454 / 0.405)$

\section{Discussion}

Fragility fractures of the pelvis will be of growing significance in older adult trauma patients over the next years, as they cause immobility and a decline in independency. Besides well-known orthogeriatric fracture patterns like proximal femur or humeral fractures, still too little attention is given on FFP. In the present register-based analysis, we hypothesized that there is still a lack of adequate evaluation in patients suffering a FFP, that vitamin D deficiency and subsequent osteoporosis or osteomalacia prevail in the assessed patients, and that vitamin D levels may correlate with different fracture patterns.

The first key finding shows that only little attention was paid on genesis of the fragility fractures during inpatient stay. The small number of patients screened for vitamin $\mathrm{D}$ deficiency and/or examined via DXA measurement is also common and known from other studies; Smith et al. presented in a recent cohort review that in 947 pelvic fragility fracture patients, $90.8 \%$ never received a DXA 
Table 2 Treatment regimens of different types of FFP

\begin{tabular}{llllll}
\hline Total patients & $\begin{array}{l}\text { FFP type I } \\
n=57\end{array}$ & $\begin{array}{l}\text { FFP type II } \\
n=304\end{array}$ & $\begin{array}{l}\text { FFP type III } \\
n=73\end{array}$ & $\begin{array}{l}\text { FFP type IV } \\
n=22\end{array}$ & $p$-value \\
\hline Conservative, $n(\%)$ & $56(98.2)$ & $272(89.5)$ & $50(68.5)$ & $9(40.9)$ & \\
Operative, $n(\%)$ & $1(1.8)$ & $32(10.5)$ & $23(31.5)$ & $13(59.1)$ & $<0.001$ \\
\hline
\end{tabular}

Table 3 Information related on bone health diagnostics in different types of FFP

\begin{tabular}{|c|c|c|c|c|c|}
\hline Total patients & $\begin{array}{l}\text { FFP type I } \\
n=57\end{array}$ & $\begin{array}{l}\text { FFP type II } \\
n=304\end{array}$ & $\begin{array}{l}\text { FFP type III } \\
n=73\end{array}$ & $\begin{array}{l}\text { FFP type IV } \\
n=22\end{array}$ & $p$-value \\
\hline \multirow{2}{*}{$\begin{array}{l}\text { Serum } 25(\mathrm{OH}) \text {-vitamin D level } \\
(\mathrm{ng} / \mathrm{ml} ; \text { mean } \pm \mathrm{SD})\end{array}$} & $n=12$ & $n=112$ & $n=31$ & $n=14$ & \\
\hline & $17.67 \pm 12.95$ & $14.09 \pm 15.09$ & $16.89 \pm 15.57$ & $25.92 \pm 11.57$ & 0.042 \\
\hline \multirow{2}{*}{$\begin{array}{l}\text { T-score (DXA scan) lumbar vertebrae } \\
(\text { mean } \pm \text { SD) }\end{array}$} & $n=10$ & $n=65$ & $n=18$ & $n=6$ & \\
\hline & $-1.76 \pm 1.36$ & $-2.07 \pm 1.57$ & $-2.69 \pm 1.26$ & $-2.80 \pm 1.13$ & ns \\
\hline \multirow{2}{*}{$\begin{array}{l}\text { T-score (DXA scan) femoral neck } \\
(\text { mean } \pm \text { SD) }\end{array}$} & $n=10$ & $n=65$ & $n=18$ & $n=6$ & \\
\hline & $-2.19 \pm 2.18$ & $-2.59 \pm 1.16$ & $-2.57 \pm 1.18$ & $-2.80 \pm 0.76$ & $\mathrm{~ns}$ \\
\hline $\begin{array}{l}\text { Alkaline phosphatase } \\
(\mathrm{U} / \mathrm{l} ; \text { mean } \pm \mathrm{SD})\end{array}$ & $\begin{array}{l}n=19^{*} \\
111.16 \pm 46.37 \\
n=3^{\circ} \\
161.33 \pm 82.86\end{array}$ & $\begin{array}{l}n=135^{*} \\
107.16 \pm 73.91 \\
n=31^{\circ} \\
100.16 \pm 44.19\end{array}$ & $\begin{array}{l}n=36^{*} \\
117.25 \pm 112.36 \\
n=8^{\circ} \\
99.50 \pm 31.64\end{array}$ & $\begin{array}{l}n=14^{*} \\
150.57 \pm 102.94 \\
n=2^{\circ} \\
162.00 \pm 69.30\end{array}$ & $\begin{array}{l}\text { ns } \\
\text { ns }\end{array}$ \\
\hline $\begin{array}{l}\text { Serum calcium }^{1} \\
(\mathrm{mmol} / \mathrm{l} ; \text { mean } \pm \mathrm{SD})\end{array}$ & $\begin{array}{l}n=18 \\
2.30 \pm 0.29\end{array}$ & $\begin{array}{l}n=149 \\
2.36 \pm 0.12\end{array}$ & $\begin{array}{l}n=38 \\
2.38 \pm 0.12\end{array}$ & $\begin{array}{l}n=13 \\
2.39 \pm 0.10\end{array}$ & $\mathrm{~ns}$ \\
\hline $\begin{array}{l}\text { Serum phosphate }{ }^{2} \\
(\mathrm{mg} / \mathrm{dl} ; \text { mean } \pm \mathrm{SD})\end{array}$ & $\begin{array}{l}n=18 \\
3.30 \pm 0.86\end{array}$ & $\begin{array}{l}n=148 \\
3.15 \pm 0.81\end{array}$ & $\begin{array}{l}n=38 \\
3.13 \pm 0.61\end{array}$ & $\begin{array}{l}n=13 \\
3.13 \pm 0.30\end{array}$ & $\mathrm{~ns}$ \\
\hline
\end{tabular}

*Female patients (range 35-105 U/l); ${ }^{\circ}$ male patients (range 40-130 U/l)

${ }^{1}$ Serum calcium range $2.05-2.65 \mathrm{mmol} / \mathrm{l} ;{ }^{2}$ serum phosphate range $2.5-4.8 \mathrm{mg} / \mathrm{dl}$

Table 4 Information related on bone health in patients with vitamin $\mathrm{D}$ insufficiency and regular vitamin $\mathrm{D}$ levels

\begin{tabular}{|c|c|c|c|}
\hline Total patients & $\begin{array}{l}\text { Vitamin D insuf- } \\
\text { ficiency } \\
(21-29 \mathrm{ng} / \mathrm{ml}) \\
n=28\end{array}$ & $\begin{array}{l}\text { Regular } \\
\text { Vitamin D } \\
\text { levels } \\
(>30 \mathrm{ng} / \mathrm{ml}) \\
n=33\end{array}$ & $p$-value \\
\hline $\begin{array}{l}\text { Alkaline phosphatase } \\
(\mathrm{U} / \mathrm{l} ; \text { mean } \pm \mathrm{SD})\end{array}$ & $\begin{array}{c}n=27 \\
86.85 \pm 36.30\end{array}$ & $\begin{array}{c}n=32 \\
112.0 \pm 86.02\end{array}$ & 0.162 \\
\hline $\begin{array}{l}\text { Serum calcium }^{1} \\
(\mathrm{mmol} / \mathrm{l} ; \text { mean } \pm \mathrm{SD})\end{array}$ & $\begin{array}{c}n=28 \\
2.16 \pm 0.17\end{array}$ & $\begin{array}{c}n=31 \\
2.23 \pm 0.19\end{array}$ & 0.135 \\
\hline $\begin{array}{l}\text { Serum phosphate }{ }^{2} \\
(\mathrm{mg} / \mathrm{dl} ; \text { mean } \pm \mathrm{SD})\end{array}$ & $\begin{array}{c}n=27 \\
3.13 \pm 0.55\end{array}$ & $\begin{array}{c}n=33 \\
3.29 \pm 0.78\end{array}$ & 0.344 \\
\hline
\end{tabular}

${ }^{1}$ Serum calcium range $2.05-2.65 \mathrm{mmol} / \mathrm{l} ;{ }^{2}$ serum phosphate range $2.5-4.8 \mathrm{mg} / \mathrm{dl}$

scan (before and after fracture) and 67.3\% never received medication for osteoporosis during their study period [20]. Considering the initially mentioned increase in the geriatric population and following increase in fragility fractures, improving this diagnostic lack is of utmost importance for secondary fracture prevention. Already existing programs like a Fracture Liason Service therefore have to be further developed and disseminated [21].
In the assessed patients, a high prevalence of vitamin D deficiency was observed. In $62.7 \%$ of the patients that were screened for vitamin D deficiency by laboratory measurements during their inpatient stay, a serum $25(\mathrm{OH})$-vitamin D level $<20 \mathrm{ng} / \mathrm{ml}$ was observed. This goes in line with previous findings by Maier et al., who reported a vitamin D deficiency in $79 \%$ of their FFP patients and identified vitamin D deficiency and osteoporosis as risk factors for pelvic insufficiency fractures [22]. DXA measurement certified an underlying osteoporosis (T-score $\leq-25)$ in $10.1 \%$ of all patients $/ 46.5 \%$ of the assessed patients, which also matches with these previous results. Besides osteoporosis, osteomalacia also has to be considered cause for fragility fractures of the pelvis, but remains neglected in most of the cases or misdiagnosed as osteoporosis. Since only patients aged 80 years and older were included, this differentiates the present study from preexisting literature, where usually a younger cohort was evaluated with lower prevalence of osteomalacia [20]. As fragility, frailty, sarcopenia, and subsequent osteomalacia intensify with advancing age, this is a major strength of the present study, because the most vulnerable cohort is appropriately represented. Laboratory measurements showed increased alkaline phosphatase levels in all female patients $/ 45.8 \%$ of all patients, 
which suggest an underlying or coexisting osteomalacia. As normal serum calcium and phosphatase levels were observed in all patients and types of FFP, no final diagnosis of osteomalacia was made. These laboratory assessments might appear irrelevant for surgical treatment, but are crucial for choosing the right drug therapy. In the vitamin D deficient type of osteomalacia, high-dose vitamin D supplementation is important, as in osteoporosis initiation of vitamin D supplementation in the beginning is followed by specific therapy after fracture healing (e.g., hormonal or bisphosphonate antiresorptive therapy). If osteoporosis is diagnosed in coexistence to osteomalacia, at first treatment of osteomalacia is completed, before fracture risk of osteoporosis is revaluated and specific treatment started if necessary.

The observed distribution of fracture patterns matches with results by Rommens and Hoffmann as well by Krappinger et al., with a major proportion of FFP type II (66.7\% in the present study vs. $51.8 \%$ Rommens/64.0\% Krappinger) $[11,23]$. To the best of our knowledge, this is the first study that compared serum $25(\mathrm{OH})$-vitamin D levels with specific fracture patterns and that evaluated different causes of FFP by laboratory and instrumental measurements. Type IV fractures with the highest degree of instability presented with the highest serum $25(\mathrm{OH})$ vitamin D level. This is counterintuitive and contrary to the results of the DXA scans, where a trend of increasingly negative $\mathrm{T}$-scores in higher grades of instability could be seen. Type IV fractures showed the lowest $\mathrm{T}$-score and presence of an underlying osteoporosis was confirmed in all of these cases, as well as indicators for a coexisting osteomalacia were present in these patients. As furthermore no correlation of vitamin D level and fracture patterns was found, the specific value seems less relevant for developing a specific fracture pattern than a low serum 25(OH)-vitamin D level per se.

Some limitations have to be considered: As a consequence of the small number of patients evaluated for an underlying osteoporosis by laboratory screenings and DXA scans, the data obtained could be biased, as values of one fracture pattern group might be disproportionately represented then another. Also evaluation for indicators of an underlying osteomalacia was based on laboratory measurements only, no verification was conducted (e.g., by bone biopsy of the iliac crest); therefore, a coexistence of osteomalacia and osteoporosis could not have been ruled out finally. To further evaluate the experienced differences between the individual fracture patterns, adding a control group would have been beneficial; as the study population only consists of patients suffering a FFP after trauma and a retrospective analysis was performed, defining this control group was not feasibly.

\section{Conclusion}

The present study showed a high amount of missed information related on bone health in geriatric patients suffering a fragility fracture of the pelvis, although this remains the essential procedure for the initation of secondary fracture prevention. In the assessed patients, a high prevalence of vitamin D deficiency was observed. While surgical treatment options were unified, a precise evaluation of the underlying pathology remains crucial for further drug therapy and sufficient secondary fracture prevention. Therefore, this is the first study that highlighted the still neglected osteological evaluation and subsequent differing etiology of fragility fractures of the pelvis, regarding osteoporosis and/or osteomalacia, based on laboratory and instrumental measurements. This evaluation should become a standardized procedure in the treatment of orthogeriatric patients presenting with a FFP. A following prospective study will try to verify these results and to identify predictors for hypovitaminosis $\mathrm{D}$ in this collective of vulnerable orthogeriatric patients.

Funding Open Access funding enabled and organized by Projekt DEAL.

Data availability The data presented in this study are available on request from the corresponding author. The data are not publicly available due to privacy reasons.

Code availability Not applicable.

\section{Declarations}

Ethics approval The study was conducted according to the guidelines of the Declaration of Helsinki and approved by the local Ethics Committee (Reg. No. 518-18).

Consent to participate All patients or their legal representative gave written informed consent for inclusion.

Consent for publication This manuscript does not contain any individual person's data in any form. All data were analyzed anonymously and published as aggregates.

Conflict of interest The authors declare no competing interests.

Open Access This article is licensed under a Creative Commons Attribution-NonCommercial 4.0 International License, which permits any non-commercial use, sharing, adaptation, distribution and reproduction in any medium or format, as long as you give appropriate credit to the original author(s) and the source, provide a link to the Creative Commons licence, and indicate if changes were made. The images or other third party material in this article are included in the article's Creative Commons licence, unless indicated otherwise in a credit line to the material. If material is not included in the article's Creative Commons licence and your intended use is not permitted by statutory regulation or exceeds the permitted use, you will need to obtain permission 
directly from the copyright holder. To view a copy of this licence, visit http://creativecommons.org/licenses/by-nc/4.0/.

\section{References}

1. Sambrook PN, Cameron ID, Chen JS et al (2007) Influence of fall related factors and bone strength on fracture risk in the frail elderly. Osteoporos Int. https://doi.org/10.1007/ s00198-006-0290-z

2. Rau CS, Lin TS, Wu SC et al (2014) Geriatric hospitalizations in fall-related injuries. Scand J Trauma Resusc Emerg Med. https:// doi.org/10.1186/s13049-014-0063-1

3. McCloskey E, Rathi J, Heijmans S et al (2021) The osteoporosis treatment gap in patients at risk of fracture in European primary care: a multi-country cross-sectional observational study. Osteoporos Int 32:251-259. https://doi.org/10.1007/ s00198-020-05557-z

4. Häussler B, Gothe H, Göl D et al (2007) Epidemiology, treatment and costs of osteoporosis in Germany - the BoneEVA study. Osteoporos Int. https://doi.org/10.1007/s00198-006-0206-y

5. Hadji P, Klein S, Haüssler B et al (2013) The bone evaluation study (BEST): patient care and persistence to treatment of osteoporosis in Germany. Int J Clin Pharmacol Ther. https://doi.org/10. 5414/CP201931

6. Trajanoska K, Schoufour JD, de Jonge EAL et al (2018) Fracture incidence and secular trends between 1989 and 2013 in a population based cohort: the Rotterdam study. Bone. https://doi.org/10. 1016/j.bone.2018.06.004

7. Sullivan MP, Baldwin KD, Donegan DJ et al (2014) Geriatric fractures about the hip: divergent patterns in the proximal femur, acetabulum, and pelvis. Orthopedics. https://doi.org/10.3928/ 01477447-20140225-50

8. World Health Organization (1998) Guidelines for preclinical evaluation and clinical trials in osteoporosis. WHO Library Cataloguing, World Health Organization, p 74

9. Bogoch ER, Elliot-Gibson V, Beaton DE et al (2006) Effective initiation of osteoporosis diagnosis and treatment for patients with a fragility fracture in an orthopaedic environment. J Bone Joint Surg Am. https://doi.org/10.2106/JBJS.E.00198

10. Meinberg EG, Agel J, Roberts CS et al (2018) Fracture and dislocation classification compendium-2018. J Orthop Trauma 32:S1S170. https://doi.org/10.1097/BOT.0000000000001063

11. Rommens PM, Hofmann A (2013) Comprehensive classification of fragility fractures of the pelvic ring: recommendations for surgical treatment. Injury. https://doi.org/10.1016/j.injury.2013.06. 023
12. Wagner D, Kamer L, Sawaguchi T et al (2016) Sacral bone mass distribution assessed by averaged three-dimensional CT models. J Bone Joint Surg 98:584-590. https://doi.org/10.2106/JBJS.15. 00726

13. Campbell SE, Fajardo RS (2008) Imaging of stress injuries of the pelvis. Semin Musculoskelet Radiol 12:62-71. https://doi.org/10. 1055/s-2008-1067938

14. Minisola S, Colangelo L, Pepe J et al (2021) Osteomalacia and vitamin D status: a clinical update 2020. JBMR Plus 5:1-6. https://doi.org/10.1002/jbm4.10447

15. Wang N, Chen Y, ... Yu B (2020) The relationship between serum vitamin D and fracture risk in the elderly: a meta-analysis. J Orthop Surg Res 15: https://doi.org/10.1186/s13018-020-01603-y

16. Maier GS, Seeger JB, Horas K et al (2015) The prevalence of vitamin $\mathrm{D}$ deficiency in patients with vertebral fragility fractures. Bone Joint J 97-B:89-93. https://doi.org/10.1302/0301-620X. 97B1.34558

17. Holick MF, Binkley NC, Bischoff-Ferrari HA et al (2011) Evaluation, treatment, and prevention of vitamin D deficiency: an Endocrine Society clinical practice guideline. J Clin Endocrinol Metab 96:1911-1930. https://doi.org/10.1210/jc.2011-0385

18. Ross AC, Manson JE, Abrams SA et al (2011) The 2011 report on dietary reference intakes for calcium and vitamin $\mathrm{D}$ from the Institute of Medicine: what clinicians need to know. J Clin Endocrinol Metab 96:53-58. https://doi.org/10.1210/jc.2010-2704

19. Cosman F, de Beur SJ, LeBoff MS et al (2014) Clinician's guide to prevention and treatment of osteoporosis. Osteoporos Int 25:2359-2381. https://doi.org/10.1007/s00198-014-2794-2

20. Smith CT, Barton DW, Piple AS, Carmouche JJ (2021) Pelvic fragility fractures. J Bone Joint Surg 103:213-218. https://doi. org/10.2106/jbjs.20.00738

21. Wu CH, Te TuS, Chang YF et al (2018) Fracture liaison services improve outcomes of patients with osteoporosis-related fractures: a systematic literature review and meta-analysis. Bone 111:92100. https://doi.org/10.1016/j.bone.2018.03.018

22. Maier GS, Kolbow K, Lazovic D et al (2016) Risk factors for pelvic insufficiency fractures and outcome after conservative therapy. Arch Gerontol Geriatr 67:80-85. https://doi.org/10.1016/j.archg er.2016.06.020

23. Krappinger D, Kaser V, Kammerlander C et al (2019) Inter- and intraobserver reliability and critical analysis of the FFP classification of osteoporotic pelvic ring injuries. Injury 50:337-343. https://doi.org/10.1016/j.injury.2018.11.027

Publisher's note Springer Nature remains neutral with regard to jurisdictional claims in published maps and institutional affiliations. 